\title{
Assessment of selected elite lines from CIMMYT's semi-arid and collaborative wheat yield trials in advanced stage of testing under the agro climatic condition of Kohat, Khyber Pakhtunkhwa
}

Salka Hameed ${ }^{1,2^{*}}$, Muhammad Ishaq ${ }^{1}$, Niaz Muhammad ${ }^{1}$, Zahid Saleem ${ }^{1}$, Zahid Iqbal $^{1}$, Javed Iqbal ${ }^{1}$, Sadia Mukhtiar ${ }^{3}$, Sufyan Qureshi ${ }^{1}$, Abdus Samad ${ }^{1}$, Qasim Jan ${ }^{1}$, Gohar Hayat ${ }^{1}$ and Tayab Ur Rahman ${ }^{1}$

1. Barani Agricultural Research Station Jarma, Kohat Khyber Pakhtunkhwa-Pakistan

2. Department of Plant Breeding and Genetics, The University of Agriculture, Peshawar, Pakistan

3. Agriculture Research Institute Tarnab, Peshawar, Pakistan

*Corresponding author's email: salkahameed911@gmail.com

Citation

Salka Hameed, Muhammad Ishaq, Niaz Muhammad, Zahid Saleem, Zahid Iqbal, Javed Iqbal, Sadia Mukhtiar, Sufyan Qureshi, Abdus Samad, Qasim Jan, Gohar Hayat and Tayab Ur Rahman. Assessment of selected elite lines from CIMMYT's semi-arid and collaborative wheat yield trials in advanced stage of testing under the agro climatic condition of Kohat, Khyber Pakhtunkhwa. Pure and Applied Biology. Vol. 11, Issue 4, pp871-880.

http://dx.doi.org/10.19045/bspab.2022.110089

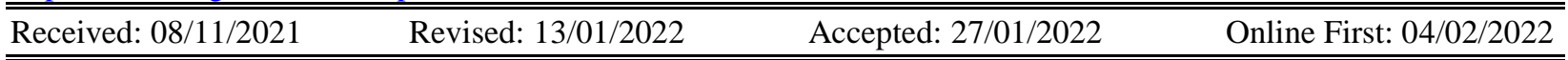

\section{Abstract}

Drastic climatic changes among the regions had seriously affected production of many crops worldwide especially wheat and considered as one of the threats to global food production and food security. Keeping in view the demand of ever-increasing population under the changing scenario of climatic changes, development of new high yielding resilient cultivars, with wider adaptation are prerequisites. In the light of such circumstances the study was conducted at Barani Agriculture Research Station Kohat to assess lines in advanced stage which was selected from CIMMYT's Semi-arid and Collaborative wheat yield trials. Analysed data showed presences of genetic variability among studied genotypes. Days to heading, plant height and grain yield varied from 121 to 129 days, 91.5 to $113.5 \mathrm{~cm}$ and $2266.7 \mathrm{~kg} / \mathrm{ha}$ to $6541.7 \mathrm{~kg} / \mathrm{ha}$, respectively. Amongst all the lines, EBWL-18 headed earlier (121 days), EBWL-41 produced tallest (113 $\mathrm{cm}$ ) plants and EBWL-15 gave maximum grain yield $(6541.7 \mathrm{~kg} / \mathrm{ha}$ ). Heritability ranges from $46 \%$ (grain yield) to $86 \%$ (plant height). Negative selection differential was noted for days to heading (-20.67) and plant height $(-15.88 \mathrm{~cm})$ while positive $(202.10 \mathrm{~kg} / \mathrm{ha})$ for grain yield which is favorable. Response to selection was $3.3,8.1 \mathrm{~cm}$ and $542.9 \mathrm{~kg} / \mathrm{ha}$ for days to heading, plant height and grain yield, respectively. Correlation analysiss showed that plant height had positive significant $(\mathrm{P}<0.5)$ correlations with grain yield. EBWL-15 performed better then check at Kohat (Khyber Pakhtunkhwa, Pakistan) in terms of phenotype and grain yield, thus it could be used in future wheat breeding program for the semi-arid region.

Keywords: CIMMYT; Collaborative; Elite Lines; Semi-arid; Wheat; Yield

\section{Introduction}

Wheat is the main food crop across the world and cultivates on millions of hectares [1].
Wheat alone meets the nutritional needs of $40 \%$ of the world population [2] All around the world, China is the largest producer of 
wheat with the production of 134,250 thousand tons [3]. Wheat is one of Pakistan's four staple food and $80 \%$ of farmers grow wheat on an area of almost 9 million hectares, which is $40 \%$ of country's arable land [4]. In Pakistan, during 2020-21, wheat was grown on an area of 9177.6 thousand hectares which resulted in a production of 27293.4 thousand tons [5]. This production is still insufficient to feed the ever-growing population of Pakistan and the world. To meet the hunger of the world, it is necessary to improve the genetic potential of cereals, especially wheat, which is the main source of calories worldwide. Development of hybrid crops are usually based on 'outbreeding enhancement' and is very common for cross-pollinated species [6] but apart from traditional selection approaches for self-pollinated crops, a lot of emphasis is given to develop hybrid wheat in USA, China, Europe and India [7] as hybrids possess the potential to deliver a major lift in production. Being the staple food of developing countries, along with fulfilling the calories requirements, wheat can also be used to overcome the hidden hunger (micronutrient deficiency) in humans by incorporating the micronutrients (e.g. iron) in wheat [8]. For this reason, the testing and evaluation of the genetic potential of wheat under various agro-climatic conditions are an urgent need. Wheat has the ability to grow under wide range of agroclimatic condition. Climatic change makes the crop productivity less predictable hence rapid climate change underline the need for genetic intervention to improve crop productivity [9]. Because of the different climatic conditions in wheat growing areas, breeders recommend lines suitable for that specific environment. Therefore, selecting wheat lines with good genetic potential for the target environment is the basis of most of wheat breeding programs. On this basis, this research was conducted to assess the genetic potential of elite lines, selected from international trials (i.e. from CIMMYT, s Semi-arid and collaborative wheat yield trials), in agro-climatic conditions of Kohat and to select the best performing lines for this environment.

\section{Materials and Methods}

This research was conducted under field condition at Barani Agriculture research station Kohat during the rabbi season of 2020-21 with the purpose of identifying the best performing line in agro-climatic conditions of Kohat. The experimental material consisted of 55 genotypes including 25 elite lines selected from $27^{\text {th }}$ semi-arid wheat yield trial $\left(27^{\mathrm{TH}}\right.$ SAWYT 2019-20) and 24 elite lines from $2^{\text {nd }}$ collaborative wheat yield trial (2 ${ }^{\text {nd }}$ CWYT 2019-20) as well as with six check cultivars i.e. Kohat-17, Fahim-19, Pirsabak-2015, Wadaan-2017, Gulzar-2019 and Pirsabak-2019. Detailed information is presented in (Table 1). These elite lines along with check cultivars were planted in $11 \times 5$ alpha lattice design with two replications on $3^{\text {rd }}$ November, 2020. Each entry is planted in 4 rows of 2-meter length each with row spacing of $30 \mathrm{~cm}$. Standard culture practices was followed during the season. Data were recorded on following parameters

\section{Days to heading (no)}

This data was recorded by counting the number of days from the date of sowing to the stage when $50 \%$ heads in the plot were become fully visible.

\section{Plant height (cm)}

Height of 5 randomly selected plants per entry was taken by measuring the length of plant from ground to tip of the spike without awns and then averaged.

\section{Grain yield (kg/ha)}

Weight of the kernals harvested from each plot was measured by using balance in $\mathrm{kg} / \mathrm{plot}$ and then converted into $\mathrm{kg} / \mathrm{ha}$. 
Table 1. List of the 55 studied wheat genotypes along with their pedigree

\begin{tabular}{|c|c|c|}
\hline Genotype & $\begin{array}{c}\text { Selection Source } \\
(2019-20)\end{array}$ & Pedigree Information \\
\hline EBWL-1 & $\begin{array}{l}\text { 27th SAWYT Entry } \\
\text { No .04 }\end{array}$ & NADI/COPIO//NADI\#2 \\
\hline EBWL-2 & $\begin{array}{l}\text { 27th SAWYT Entry } \\
\text { No } 5\end{array}$ & $\mathrm{KUTZ} / / \mathrm{KFA} / 2 * \mathrm{KACHU}$ \\
\hline EBWL-3 & $\begin{array}{l}\text { 27th SAWYT Entry } \\
\text { No } 6\end{array}$ & BOKOTA//KFA/2*KACHU \\
\hline EBWL-4 & $\begin{array}{l}\text { 27th SAWYT Entry } \\
\text { No } 8\end{array}$ & SLVS/ATTILA//WBLL1*2/3/GONDO/CBRD/4/BORL14 \\
\hline EBWL-5 & $\begin{array}{l}\text { 27th SAWYT Entry } \\
\text { No } 9\end{array}$ & SLVS/ATTILA//WBLL1*2/3/GONDO/CBRD/4/BORL14 \\
\hline EBWL-6 & $\begin{array}{l}\text { 27th SAWYT Entry } \\
\text { No } 12\end{array}$ & 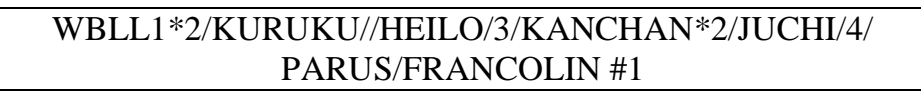 \\
\hline EBWL-7 & $\begin{array}{l}\text { 27th SAWYT Entry } \\
\text { No } 13\end{array}$ & $\begin{array}{c}\text { BORL14*2/7/MUU/5/WBLL1*2/4/YACO/PBW65/3/KAUZ } \\
* 2 / \mathrm{TRAP} / / \mathrm{KAUZ/6/WBLL1*2/SHAMA}\end{array}$ \\
\hline EBWL-8 & $\begin{array}{l}\text { 27th SAWYT Entry } \\
\text { No } 15\end{array}$ & WAXWING*2/TUKURU//KBIRD/3/2*BORL14 \\
\hline EBWL-9 & $\begin{array}{l}\text { 27th SAWYT Entry } \\
\text { No } 17\end{array}$ & $\begin{array}{l}\text { FRET2 } * 2 / \mathrm{SHAMA} / / \mathrm{KIRITATI} / 2 * \mathrm{TRCH} / 3 / \mathrm{KFA} / 2 * \mathrm{KACHU} \\
\text { /4/FRET } 2 * 2 / \mathrm{SHAMA} / \mathrm{PARUS} / 3 / \mathrm{FRET} 2 * 2 / \mathrm{KUKUNA}\end{array}$ \\
\hline EBWL-10 & $\begin{array}{l}\text { 27th SAWYT Entry } \\
\text { No } 18\end{array}$ & MUU/KBIRD//2*KACHU/KIRITATI \\
\hline EBWL-11 & $\begin{array}{l}\text { 27th SAWYT Entry } \\
\text { No } 21\end{array}$ & ATTILA*2/PBW65*2//MURGA/3/KACHU/KIRITATI \\
\hline EBWL-12 & $\begin{array}{l}\text { 27th SAWYT Entry } \\
\text { No } 22\end{array}$ & WBLL1*2/CHAPIO*2//MURGA/3/MUTUS/AKURI \\
\hline EBWL-13 & $\begin{array}{l}\text { 27th SAWYT Entry } \\
\text { No } 23\end{array}$ & MUTUS/ROLF07//MUCUY \\
\hline EBWL-14 & $\begin{array}{l}\text { 27th SAWYT Entry } \\
\text { No } 24\end{array}$ & $\begin{array}{c}\text { ALTAR 84/AE.SQUARROSA (221)//3*BORL95/3 } \\
\text { /URES/JUN//KAUZ/4/WBLL1/5/MUTUS/6/SUP152/BAJ \#1 }\end{array}$ \\
\hline EBWL-15 & $\begin{array}{l}\text { 27th SAWYT Entry } \\
\text { No } 25\end{array}$ & $\begin{array}{c}\text { CHRZ//BOW/CROW/3/WBLL1/4/CROC_1/AE.SQUARROSA } \\
(213) / / \text { PGO/5/BORL14 }\end{array}$ \\
\hline EBWL-16 & $\begin{array}{l}\text { 27th SAWYT Entry } \\
\text { No } 26\end{array}$ & $\begin{array}{l}\text { PREMIO/4/CROC_1/AE.SQUARROSA (205)//KAUZ/3/ } \\
\text { PIFED/5/BORL14 }\end{array}$ \\
\hline EBWL-17 & $\begin{array}{l}\text { 27th SAWYT Entry } \\
\text { No } 27\end{array}$ & SNTL/3/KACHU//WBLL1*2/BRAMBLING \\
\hline EBWL-18 & $\begin{array}{l}\text { 27th SAWYT Entry } \\
\text { No } 28\end{array}$ & BORL14*2//BECARD/QUAIU \#1 \\
\hline EBWL-19 & $\begin{array}{l}\text { 27th SAWYT Entry } \\
\text { No } 29\end{array}$ & BORL14*2//BECARD/QUAIU \#1 \\
\hline EBWL-20 & $\begin{array}{l}\text { 27th SAWYT Entry } \\
\text { No } 32\end{array}$ & $\begin{array}{c}\text { FRANCOLIN \#1//WBLL1 } * 2 / B R A M B L I N G / 3 / \\
\text { WBLL1 } * 2 / B R A M B L I N G / 4 / 2 * N A D I \# 1\end{array}$ \\
\hline EBWL-21 & $\begin{array}{l}\text { 27th SAWYT Entry } \\
\text { No } 33\end{array}$ & $\begin{array}{c}\text { KACHU \#1//WBLL1*2/KUKUNA/3/BRBT1*2/KIRITATI } \\
\text { /6/ROLF07*2/5/REH/HARE//2*BCN/3/CROC_1 } \\
\text { /AE.SQUARROSA (213)//PGO/4/HUITES/7/BORL14 }\end{array}$ \\
\hline EBWL-22 & $\begin{array}{l}\text { 27th SAWYT Entry } \\
\text { No } 36\end{array}$ & $\begin{array}{c}\text { WBLL1 } * 2 / B R A M B L I N G * 2 / / B A V I S / 4 / S W S R 22 T . B . / / \\
\text { TACUPETO F2001*2/BRAMBLING/3/2* } \\
\text { TACUPETO F2001*2/BRAMBLING }\end{array}$ \\
\hline EBWL-23 & $\begin{array}{l}\text { 27th SAWYT Entry } \\
\text { No } 37\end{array}$ & $\begin{array}{c}\text { TRCH*2//ND643/2*WBLL1/3/SWSR22T.B./2* } \\
\text { BLOUK \#1//WBLL1*2/KURUKU }\end{array}$ \\
\hline EBWL-24 & $\begin{array}{l}\text { 27th SAWYT Entry } \\
\text { No } 46\end{array}$ & $\begin{array}{c}\text { ELVIRA/5/CNDO/R143//ENTE/MEXI75/3/AE.SQ } \\
\text { /4/2*OCI/6/VEE/PJN//KAUZ/3/PASTOR/7/KIRITATI/4/2* } \\
\text { SERI.1B*2/3/KAUZ*2/BOW//KAUZ/8/ELVIRA/5/CNDO/ } \\
\text { R143//ENTE/MEXI75/3/AE.SQ/4/2*OCI/6/VEE/PJN// }\end{array}$ \\
\hline
\end{tabular}




\begin{tabular}{|c|c|c|}
\hline & & KAUZ/3/PASTOR/9/BORL14 \\
\hline EBWL-25 & 2nd CWYT Entry No 3 & $\begin{array}{l}\text { KACHU/SAUAL/4/ATTILA } * 2 / \text { PBW65//PIHA/3/ATTILA/ } \\
2 * \text { PASTOR }\end{array}$ \\
\hline EBWL-26 & 2nd CWYT Entry No 5 & MUNAL*2/WESTONIA \\
\hline EBWL-27 & $\begin{array}{l}\text { 2nd CWYT Entry No } \\
6\end{array}$ & $\begin{array}{c}\text { UP2338*2/SHAMA/3/MILAN/KAUZ//CHIL/CHUM18/4/ } \\
\text { UP2338*2/SHAMA } * 2 / 5 / \text { PBW343*2/KUKUNA2//FRTL/PIFED }\end{array}$ \\
\hline EBWL-28 & 2nd CWYT Entry No 7 & BECARD/AKURI*2/3/PBW343*2/KUKUNA*2//FRTL/PIFED \\
\hline EBWL-29 & $\begin{array}{l}\text { 2nd CWYT Entry No } \\
10\end{array}$ & KASUKO \\
\hline EBWL-30 & $\begin{array}{l}\text { 2nd CWYT Entry No } \\
11\end{array}$ & $\begin{array}{l}\text { WBLL1/FRET2//PASTOR*2/3/MURGA/5/ND643//2*ATTILA } \\
* 2 / \mathrm{PASTOR/3/WBLL1*2/KURUKU/4/WBLL1*2/BRAMBLING}\end{array}$ \\
\hline EBWL-31 & $\begin{array}{l}\text { 2nd CWYT Entry No } \\
17\end{array}$ & $\begin{array}{c}\text { FRET2/TUKURU//FRET2/3/MUNAL \#1/4/SUP152 } \\
\text { /AKURI//SUP152 }\end{array}$ \\
\hline EBWL-32 & $\begin{array}{l}\text { 2nd CWYT Entry No } \\
18\end{array}$ & NADI/COPIO//NADI\#2 \\
\hline EBWL-33 & $\begin{array}{l}\text { 2nd CWYT Entry No } \\
19\end{array}$ & $\begin{array}{c}\text { SUP152/6/OASIS/5*BORL95/5/CNDO/R143//ENTE/ } \\
\text { MEXI75/3/AE.SQ/4/2*OCI }\end{array}$ \\
\hline EBWL-34 & $\begin{array}{l}\text { 2nd CWYT Entry No } \\
20\end{array}$ & $\begin{array}{l}\text { WBLL1*2/BRAMBLING/4/BABAX/LR42//BABAX* } \\
\text { 2/3/SHAMA*2/5/PBW343*2/KUKUNA*2//FRTL/PIFED }\end{array}$ \\
\hline EBWL-35 & $\begin{array}{l}\text { 2nd CWYT Entry No } \\
\qquad 21\end{array}$ & $\begin{array}{c}\text { WAXWING/KIRITATI*2/3/C80.1/3*BATAVIA// } \\
2 * \text { WBLL1/4/COPIO/5/ND643//2*ATTILA*2/ } \\
\text { PASTOR/3/WBLL1*2/KURUKU/4/WBLL1 } * 2 / \text { BRAMBLING }\end{array}$ \\
\hline EBWL-36 & $\begin{array}{l}\text { 2nd CWYT Entry No } \\
23\end{array}$ & $\begin{array}{c}\text { LIVINGSTON/6/2*MTRWA92.161/PRINIA/5/ } \\
\text { SERI*3//RL6010/4*YR/3/PASTOR/4/BAV92 } \\
\end{array}$ \\
\hline EBWL-37 & $\begin{array}{l}\text { 2nd CWYT Entry No } \\
\qquad 24\end{array}$ & $\begin{array}{l}\text { PBW343/TONI//ELVIRA/7/CNO79//PF70354 } \\
\text { /MUS/3/PASTOR/4/BAV92/5/FRET2/KUKUNA } \\
\text { //FRET2/6/MILAN/KAUZ//PRINIA/3/BAV92 }\end{array}$ \\
\hline EBWL-38 & $\begin{array}{l}\text { 2nd CWYT Entry No } \\
\qquad 27\end{array}$ & $\begin{array}{c}\text { TACUPETO F2001/6/CNDO/R143//ENTE/MEXI_ } \\
\text { 2/3/AEGILOPS SQUARROSA (TAUS)/4/WEAVER } \\
\text { /5/PASTOR/7/ROLF07*2/8/SAUAL/YANAC//SAUAL }\end{array}$ \\
\hline EBWL-39 & $\begin{array}{l}\text { 2nd CWYT Entry No } \\
28\end{array}$ & (2) \\
\hline EBWL-40 & $\begin{array}{l}\text { 2nd CWYT Entry No } \\
29\end{array}$ & $\begin{array}{l}\text { 68.111/RGB-U//WARD/3/FGO/4/RABI/5/AE.SQUARROSA } \\
\text { (784)/6/BECARD }\end{array}$ \\
\hline EBWL-41 & $\begin{array}{l}\text { 2nd CWYT Entry No } \\
\qquad 30\end{array}$ & $\begin{array}{c}\text { 68.111/RGB-U//WARD/3/FGO/4/RABI/5/ } \\
\text { AE.SQUARROSA (778)/7/2*CHWL86/6/ } \\
\text { FILIN/IRENA/5/CNDO/R143//ENTE/ } \\
\text { MEXI_2/3/AEGILOPS SQUARROSA (TAUS)/4/WEAVER }\end{array}$ \\
\hline EBWL-42 & $\begin{array}{l}\text { 2nd CWYT Entry No } \\
32\end{array}$ & $\begin{array}{c}\text { CHEN/AE.SQ//2*OPATA/3/FINSI/5/ } \\
\text { W15.92/4/PASTOR//HXL7573/2*BAU/3/WBLL1 }\end{array}$ \\
\hline EBWL-43 & $\begin{array}{l}\text { 2nd CWYT Entry No } \\
39\end{array}$ & KAUZ/SERI//PFAU/MILAN \\
\hline EBWL-44 & $\begin{array}{l}\text { 27th SAWYT Entry } \\
\text { No } 47 \\
\end{array}$ & BAVIS/NAVJ07//BORL14 \\
\hline EBWL-45 & $\begin{array}{l}\text { 2nd CWYT Entry No } \\
44\end{array}$ & $\begin{array}{l}\text { MEX94.27.1.20/3/SOKOLL//ATTILA/3*BCN/4/ } \\
\text { NESMA*2/14-2//2*SAFI-3 }\end{array}$ \\
\hline EBWL-46 & $\begin{array}{l}\text { 2nd CWYT Entry No } \\
45\end{array}$ & $\begin{array}{l}\text { PFAU/MILAN//FUNG MAI 24/3/ACHTAR/ } \\
\text { INRA } 1764\end{array}$ \\
\hline EBWL-47 & $\begin{array}{l}\text { 2nd CWYT Entry No } \\
49\end{array}$ & WORRAKATTA/PASTOR//ACSAD- 981 \\
\hline EBWL-48 & $\begin{array}{l}\text { 2nd CWYT Entry No } \\
50\end{array}$ & $\begin{array}{c}\text { REBWAH-13/3/CMH81.38/2*KAUZ// } \\
\text { ATTILA/4/URES/BOW//OPATA/3/HD2206/HORK }\end{array}$ \\
\hline
\end{tabular}




\begin{tabular}{|c|c|c|}
\hline $\begin{array}{c}\text { Check } \\
\text { Cultivar No 1 }\end{array}$ & KT-2017 & SOKOLL/WBLLI \\
$\begin{array}{c}\text { Check } \\
\text { Cultivar No 2 }\end{array}$ & Fahim-2019 & MILLAN/KAUZ//PRINIA/3/BAV92/4/2*SOKOLL \\
\hline $\begin{array}{c}\text { Check } \\
\text { Cultivar No 3 }\end{array}$ & Pirsabak-2015 & MILAN/S87230//BABAX \\
$\begin{array}{c}\text { Check } \\
\text { Cultivar No 4 }\end{array}$ & Wadaan-2017 & YAV79//DACK/RABI/3/SNIPE/4/ AE. SQUARROSA \\
\hline EBWL-49 & SAWYT V-03 & $\begin{array}{c}\text { SOKOLL/3/PASTOR//HXL7573/2*BAU*2/6/OASIS/5 } \\
\text { BORL95/5/CNDO/R143//ENTE/MEXI75/3/AE.SQ/4/2*OCI }\end{array}$ \\
\hline $\begin{array}{c}\text { Check } \\
\text { Cultivar 5 }\end{array}$ & Gulzar- 2019) & MILLAN/S87230//BAV92*2/3/AKURI \\
$\begin{array}{c}\text { Check } \\
\text { Cultivar 6 }\end{array}$ & Pirsabak-2019) & $\begin{array}{c}\text { PASTOR//HXL7573/2*BAU/3/SOKOLL/WBLLI/4/HUW234- } \\
\text { LR34/PRINIA/PBW343*2/KAKUNA/3/ROLF07/5/WHEAR/SOKOLL }\end{array}$ \\
\hline
\end{tabular}

Data was subjected to R software (individual environment) for analysis. Formula proposed by [10] was used to calculate broad sense heritability $\left(h^{2}{ }_{(B S)}\right)$ of each trait.

$h^{2}{ }_{(B S)}=\mathrm{V}_{\mathrm{g}} /\left(\mathrm{V}_{\mathrm{g}}+\mathrm{V}_{\mathrm{e}} / \mathrm{r}\right)$

Where

$\mathrm{V}_{\mathrm{g}}=$ genetic variance

$\mathrm{Ve}=$ environmental Variance

$\mathrm{r}=$ number of replication

Selection differential (S) is calculated as the difference between the means of top $20 \%$ selected lines and overall mean of 49 selected elite lines by the method given by [11].

$\mathrm{S}=\mathrm{X}_{\mathrm{s}}-\mathrm{X}$

Where $X_{s}=$ mean of top $20 \%$ selected lines

$\mathrm{X}=$ overall mean of tested lines

Response to selection ( $\mathrm{Re}$ ) was calculated as the product of selection intensity, square root of phenotypic variance and heritability of the trait $\mathrm{x}$ by following the method proposed by [12].

$\mathrm{R}_{\mathrm{e}}=\mathrm{i}_{\mathrm{x}} \times \sqrt{ } \mathrm{V}_{\mathrm{p}} \times \mathrm{h}^{2}$

Where

$\mathrm{i}=$ selection intensity

$\sqrt{ } \mathrm{V}_{\mathrm{p}}=$ phenotypic variation

$\mathrm{h}^{2}=$ heritability

Correlation analysis was done through MVApp (Multivariate Analysis Application) [13].

\section{Results and Discussion}

\section{Days to Heading (no)}

Days to heading is an important trait in wheat as early heading provides sufficient time for grain filling, resulting in bold grain and ultimately in high yield. Minimum days to heading is favorable as it can lead to early maturity which help crop to escape from various biotic and abiotic stresses. Analyzed data of days to heading revealed significant $(\mathrm{P}<0.1)$ differences among the studied wheat genotypes with the genetic variance of 4.18 and residual variance of 1.88 , respectively (Table 2). Similar results were also reported by [14] while finding genetic diversity among wheat genotypes for breeding strategies. Overall mean values of genotypes range from 121 (EBWL-18) to 129 (Pirsabak-15, EBWL-47) days (Fig. 1) with the grand mean of 126 days (Table 2). Mean values of elite lines and check cultivar were 125.9 and 127 days, respectively. While the average mean of best $20 \%$ elite lines was 105.25 days (Table 3). High heritability (0.82) was estimated for the said trait which is a positive indication that trait is in the control of gene (Table 2). Heritability of same range was observed by $[15,16]$ during assessment of spring wheat genotypes. Response to selection for days to heading was 3.3 and selection differential was negative (20.67) similar to $[\mathbf{1 7}, \mathbf{1 8}]$ which is desirable because there is possibilities to reduce heading days which lead to early maturity (Table 3).

\section{Plant height}

Plant height has given special attention by plant breeders because due to lodging it can 
significantly affect grain yield in case of taller plants. Therefore, plants with medium height are preferred in breeding programs. The analysis result confirmed the presence of significant $(\mathrm{P}<0.1)$ differences among the experimental material having the genetic variance of 23.9 and residual variance of 8.8 (Table 2). Results of $[\mathbf{1 9}, \mathbf{2 0}]$ are in alliance with our study. Means for plant height of all wheat genotypes ranged from 91.5 (Pirsabak 15) to 113.5 (EBWL-41) (Fig. 2) with grand mean of $101.2 \mathrm{~cm}$ (Table 2). While the average means for elite lines, check cultivars and 20\% top selected lines were 101.2, 85.29, and $101.3 \mathrm{~cm}$, respectively (Table 3). Heritability was high (0.84) for plant height (Table 2) with response to selection of $8.1 \mathrm{~cm}$ (Table 3). High heritability estimate was also stated by $[\mathbf{2 0}, \mathbf{2 1}]$. Negative selection differential $(-15.88 \mathrm{~cm})$ was estimated for said trait (Table 3) and it is favorable for taller genotypes as there is chances that in next breeding cycle the height will reduce to desirable range. This result is in complete alliance with [18].

\section{Grain Yield}

The ultimate goal of most of the breeding programs is the increased grain yield and breeders are working consistently to develop new diverse germplasm to get the genotype having stable and high yield. Genotypes were significantly $(\mathrm{P}<0.1)$ different for grain yield having the genotypic and error variance of 302940.5 and 724567.4 , respectively (Table 2) $[22,23]$. Average values for said trait among wheat genotypes ranged between $2266.7 \mathrm{~kg} / \mathrm{ha}$ (Wadaan-2017) and 6541.7 $\mathrm{kg} / \mathrm{ha}$ (EBWL-15) (Fig. 3) with grand mean of $4506.4 \mathrm{~kg} / \mathrm{ha}$ (Table 2) whereas 4708.50 and $3380.6 \mathrm{~kg} / \mathrm{ha}$ are the mean values of $20 \%$ selected lines and check cultivars, correspondingly (Table 3). Heritability of grain yield was moderate (0.46) (Table 2) because of more environmental variance which is evidence by high estimate of error variance over genotypic variance. Moderate heritability was reported by [17] for grain yield under normal condition. Expected response to selection and selection differential for grain yield were $542.9 \mathrm{~kg} / \mathrm{ha}$ and $202.10 \mathrm{~kg} / \mathrm{ha}$ (Table 3). Related findings were also documented by [24] while [25] also calculated selection differential and response to selection.

Table 2. Heritability, genotypic variance, residual variance, grand mean, least significant difference (LSD), coefficient of variance (CV) and genotypic variance of days to heading, plant height and grain yield for the studied traits of 55 wheat genotypes

\begin{tabular}{|c|c|c|c|}
\hline Parameters & Days to heading & Plant height & Grain Yield \\
\hline Heritability & 0.82 & 0.84 & 0.46 \\
\hline Genotype Variance & 4.18 & 23.9 & 302940.5 \\
\hline Residual Variance & 1.88 & 8.84 & 724567.4 \\
\hline Grand Mean & 126 & 101.2 & 4506.4 \\
\hline LSD & 1.76 & 3.88 & 832.7 \\
\hline CV & 1.09 & 2.94 & 18.9 \\
\hline Genotype Significance & $* *$ & $* *$ & $* *$ \\
\hline
\end{tabular}

* Significant at 5\%,** significant at $1 \%$ 
Table 3. Means of lines, mean of $20 \%$ selected lines, means of checks, selection differential and expected response to selection for the studied traits of 55 wheat genotypes

\begin{tabular}{|c|c|c|c|c|c|}
\hline Traits & $\begin{array}{c}\text { Mean of } \\
\text { Lines }\end{array}$ & $\begin{array}{c}\text { Mean of 20\% } \\
\text { selected lines }\end{array}$ & $\begin{array}{c}\text { Mean of } \\
\text { checks }\end{array}$ & $\begin{array}{c}\text { Selection } \\
\text { differential }\end{array}$ & $\begin{array}{c}\text { Expected } \\
\text { Response (Re) }\end{array}$ \\
\hline Days to heading & 126.0 & 105.25 & 127 & -20.67 & 3.3 \\
\hline Plant height & 101.2 & 85.29 & 101.3 & -15.88 & 8.1 \\
\hline Grain Yield & 4506.4 & 4708.50 & 3380.6 & 202.10 & 542.9 \\
\hline
\end{tabular}

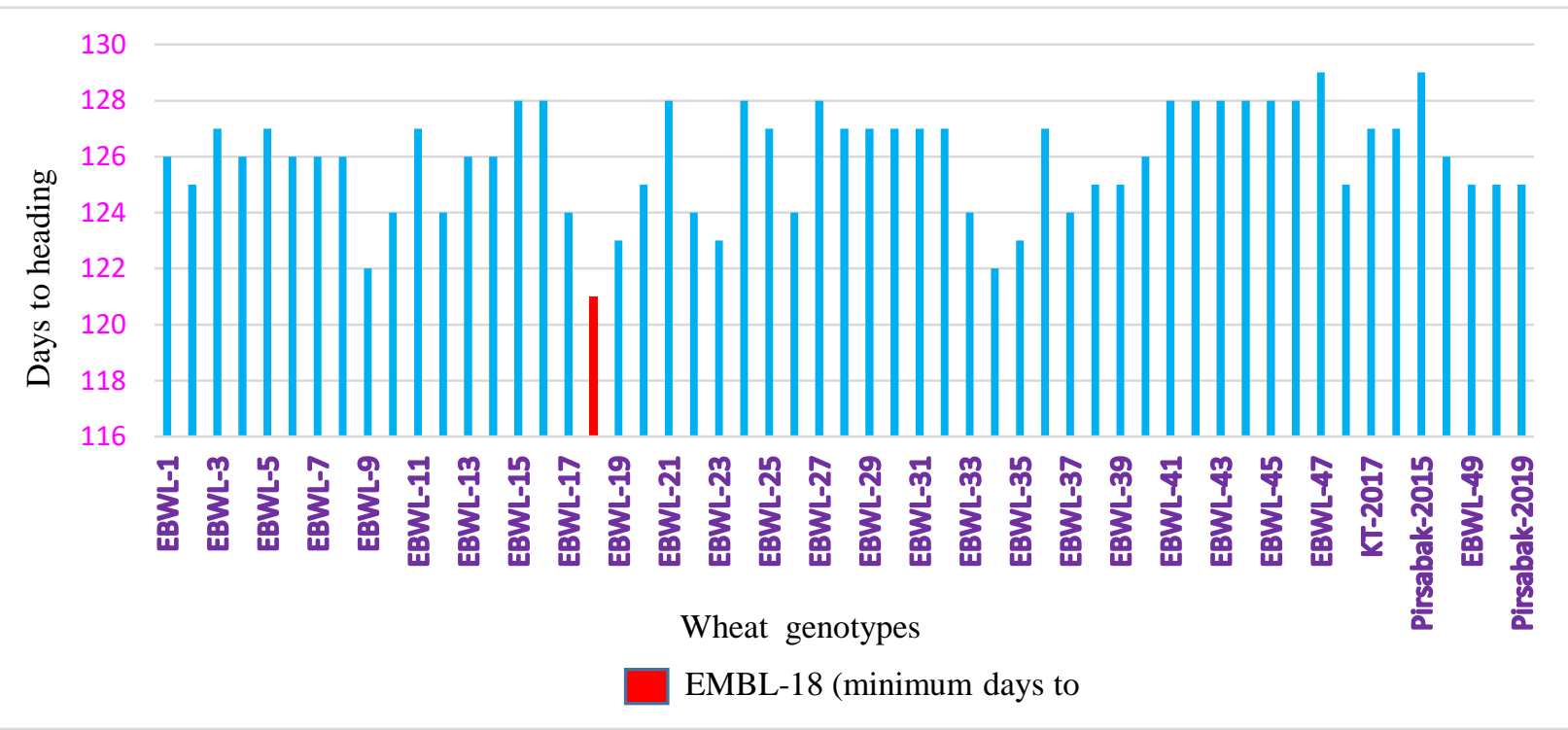

Figure 1. Mean values for days to heading of 55 wheat genotypes

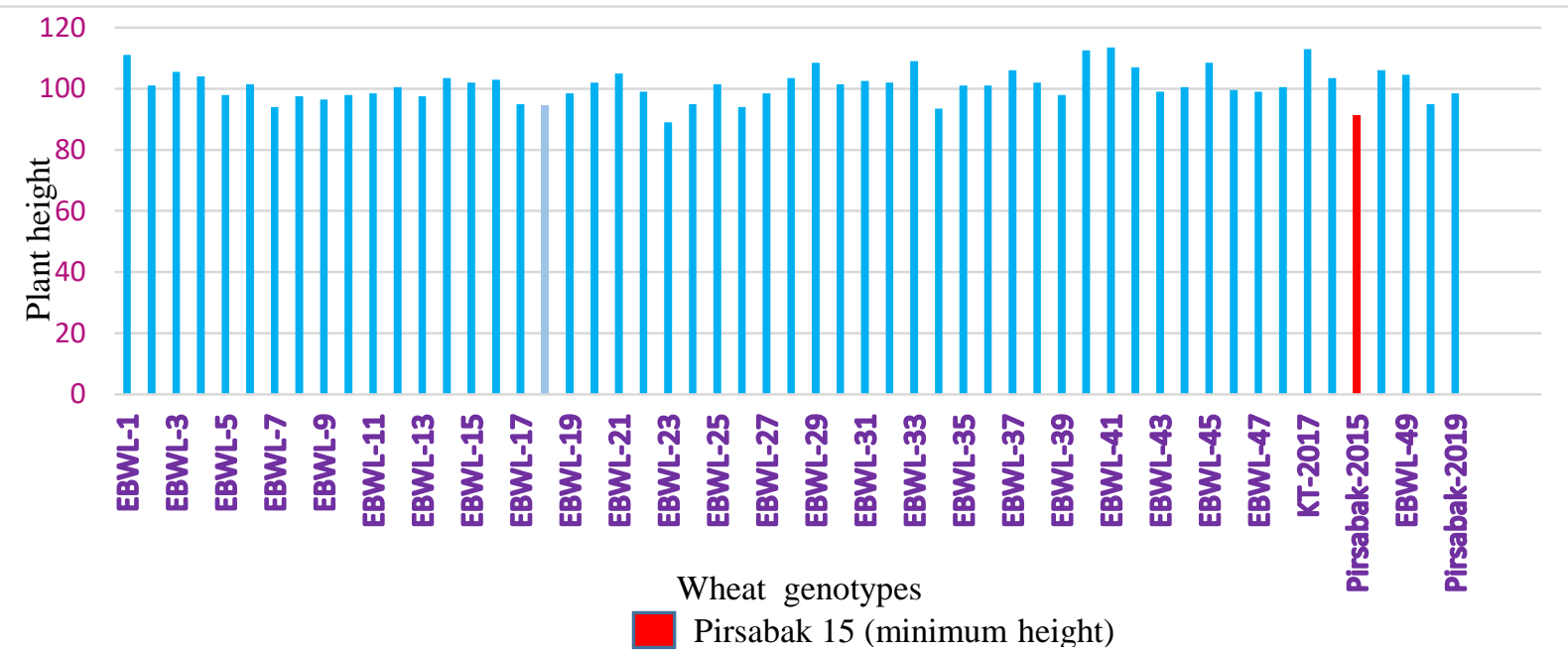

Figure 2. Mean values for plant height of 55 wheat genotypes 


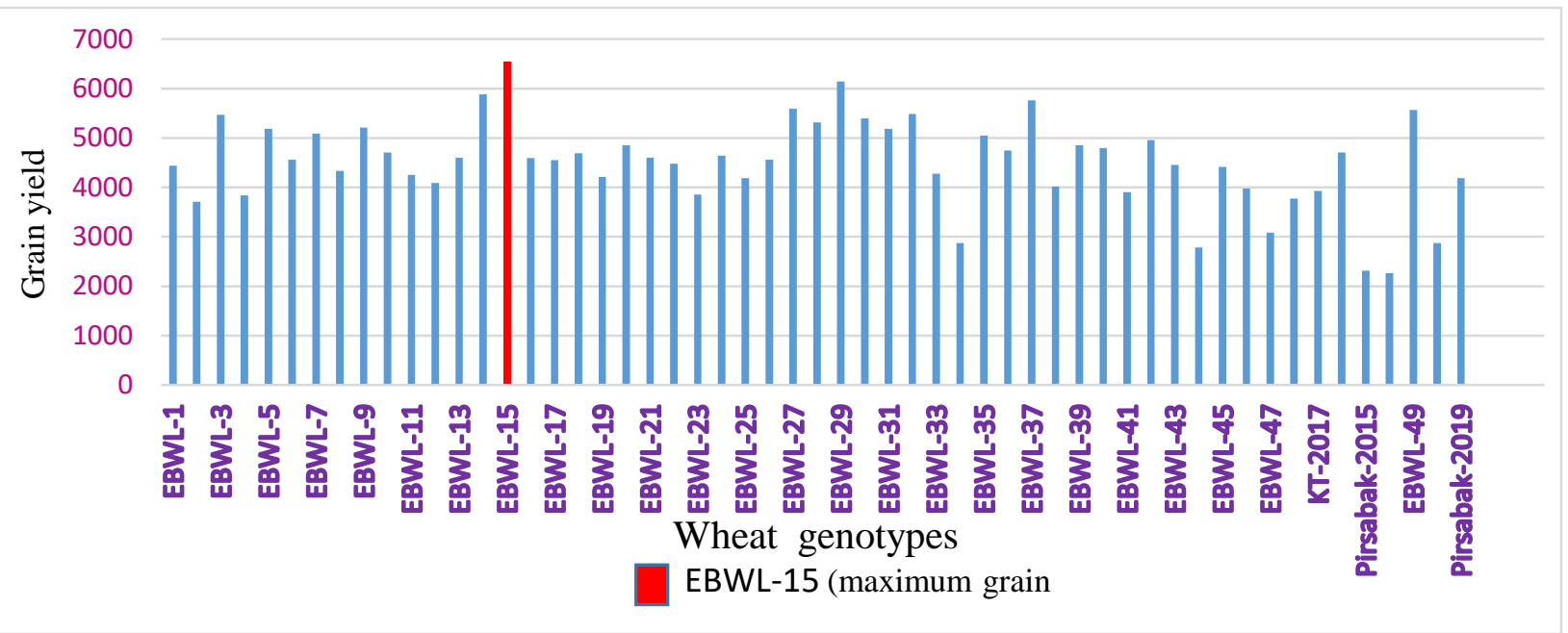

Figure 3. Mean values for grain yield of 55 wheat genotypes

\section{Correlation analysis}

Days to heading has shown a statistically significant positive correlation $(\mathrm{P}<0.5)$ with plant height. Whereas, days to heading has shown a non-significant positive correlation with grain yield. On the other hand, plant height has shown a significant positive correlation $(\mathrm{P}<0.5)$ with grain yield (Table
4). Our results are in agreement with previous study conducted by [26].

The color and size of the circle reflect the strength of the correlation. The nonsignificant correlations, with the p-value above 0.05 are indicated with a cross in the individual cells. $\mathrm{DH}=$ days to heading, $\mathrm{PH}=$ plant height, G. Yield= grain yield in $\mathrm{kg} / \mathrm{ha}$ (Fig. 4).

Table 4 Pearson's correlation among studied phenotypic traits $(\mathrm{P}<0.5)$

\begin{tabular}{|c|c|c|c|c|}
\hline Trait 1 & Trait 2 & Correlation coefficient & P value & Significance \\
\hline DH & PH & 0.315474 & 0.000788 & $*$ \\
\hline DH & G. Yield & 0.046198 & 0.631759 & ns \\
\hline PH & G. Yield & 0.193557 & 0.04276 & $*$ \\
\hline
\end{tabular}

*Significant at 5\%, DH= days to heading, $\mathrm{PH}=$ plant height, $\mathrm{G}$. Yield= grain yield in $\mathrm{kg} / \mathrm{ha}$

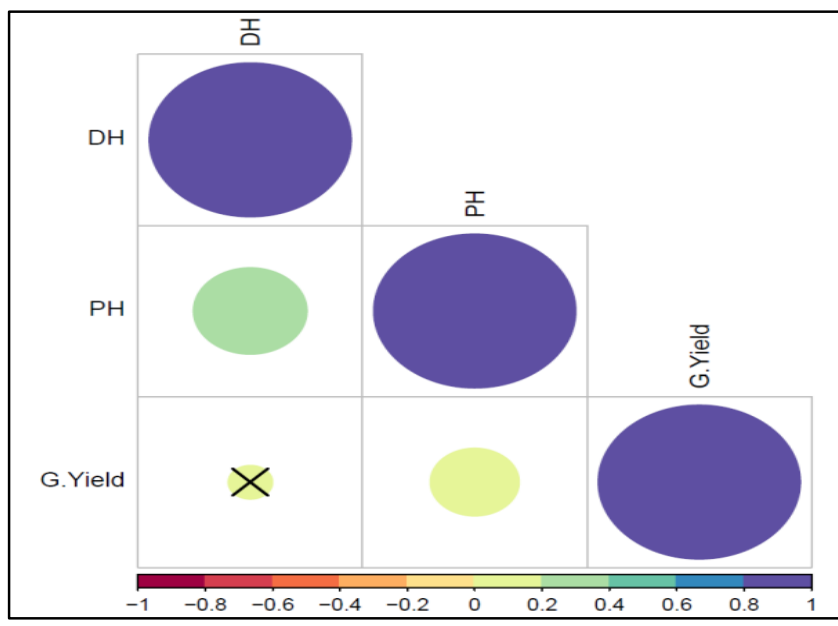

Figure 4. The figure shows the Pearson's correlation coefficients between studied traits 


\section{Conclusion and Recommendations}

Analyzed data reveled significant variation among the genotypes for the studied traits indicated that sufficient variability existed among the genotypes. (i.e. 25 elite lines selected from $27^{\text {th }}$ semi-arid wheat yield trial (27 ${ }^{\mathrm{TH}}$ SAWYT 2019-20) and 24 elite lines from $2^{\text {nd }}$ collaborative wheat yield trial $\left(2^{\text {nd }}\right.$ CWYT 2019-20) along with six check cultivar i.e. Kohat -17 , Fahim -19, and Pirsabak 2015, Wadaan-2017, Gulzar-2019 and Pirsabak-2019. Days to heading, plant height, and grain yield ranged from 121 (EBWL-18) to 129 (Pirsabak-15, EBWL-47) days, 91.5 (Pirsabak 15) to 113.5 (EBWL-41) $\mathrm{cm}$ and $2266.7 \mathrm{~kg} / \mathrm{ha}$ (Wadaan-2017) to $6541.7 \mathrm{~kg} / \mathrm{ha}$, respectively. EBWL-15 performed better then check at Kohat (Khyber Pakhtunkhwa, Pakistan) in terms of phenotype and grain yield, thus it could be used in future wheat breeding program for the semi-arid region.

\section{Author's contributions}

Conceived and design the experiment: $\mathrm{S}$ Hameed, M Ishaq \& $\mathrm{N}$ Muhammad, Performed the experiment: S Hameed, $M$ Ishaq, Z Iqbal, \& Z Saleem, Analyzed the data: $S$ Hameed, Contributed material /analysis /tools: S. Mukhtiar, S Qurashi, J Iqbal, A Samad, Q Jan, G Hayat, \& TU Rahman, Wrote the paper: S Hameed \& M Ishaq.

\section{Acknowledgements}

The authors are thankful to International maize and wheat improvement center (CIMMYT), México and National Coordinator Wheat for provision of wheat germplasm received in the form of international nurseries and trials.

\section{References}

1. Asseng S, Guarina JR, Ramanb M, Monjec O, Kissd G, Despommiere DD, Meggersf FM, \& Gauthierg PPG (2020). Wheat yield potential in controlledenvironment vertical farms. PNAS 117(32): 19131-19135.
2. Giraldo $\mathrm{P}$, Benavente E, ManzanoAgugliaro F \& Gimenez E (2019). Worldwide Research Trends on Wheat and Barley: A Bibliometric Comparative Analysis. Agronomy 9(352): 3-18.

3. World data atlas (2021). Production, supply and distribution of agriculture commodities by market year 2021 (https://knoema.com/atlas)

4. Anaymous (2019). Pakistan grain and feed annual report. Global Agriculture information network. GAIN report number: PK1907.

https://apps.fas.usda.gov/newgainapi/api /report/downloadreportbyfilename?filena me=Grain\%20and\%20Feed\%20Annual_ Islamabad_Pakistan_3-28-2019.pdf

5. Govt. of Pakistan (2020). Pakistan Statistical Year Book. Federal Bureau of Statistics Division Govt. of Pakistan. https://www.pbs.gov.pk/publications.

6. Rehman AU, Dang T, Qamar S, Ilyas A, Fatema R, Kafle M, Hussain Z, Masood S, Iqbal S, \& Shahzad K (2021). Revisiting plant heterosis- from field scale to molecules. Genes 12(11): 1688.

7. Gupta PK, Balyan HS, Gahlaut V, Saripalli G, Pal B, Basnet BR, \& Joshi AK (2019). Hybrid wheat: past, present and future. Theor and Appl Genetics 132: 2463-2483.

8. Rehman AU, Masood S, Khan NU, Abbasi ME, Hussain Z, \& Ali I (2021). Molecular basis of Iron Biofortification in crop plants; A step towards sustainability. Plant Breed 140: 12-22.

9. Reynolds M, Foulkes MJ, Slafer GA, Berry P, Parry MAJ, Snape JW \& Angus WJ (2009). Raising yield potential in wheat. J. Exp. Bot 60 (7): 1899-1918.

10. Fehr WR (1993). Principles of cultivar development. Vol. 1. Theory and technique. Macmillian Publishing Co., USA.

11. Falconer DS \& Mackay TFC (1996). Introduction to quantitative genetics. 4th 
Ed. Longman Scientific and Technical, England.

12. Frank GV, Rivière $P$, Pin $S$, Baltassat R, Berthellot JF, Caizergues F, Dalmasso C, Gascuel JS, Hyacinthe A, Mercier F, Montaz H, Ronot B \& Goldringer I (2020). Genetic diversity and stability of performance of wheat population varieties developed by participatory breeding. Sustainability 12(384):1-21.

13. Julkowska MM, Saade S, Agarwal G, Geo G, Pailles Y, Morton M, Awlia M \& Tester M (2019). MVApp-Multivariate analysis application for streamlined data analysis and curation. Plant Physiol 180: 1261-1276.

14. Khodadadi M, Fotokian MH, \& Miransari M (2011). Genetic diversity of wheat (Triticum aestivum L.) genotypes based on cluster and principal component analyses for breeding strategies. AJCS 5(1):17-24.

15. Alemu YA, Anley AM \& Abebe TG (2020). Genetic variability and association of traits in Ethiopian Durum Wheat (Triticum turgidium L. var. durum) landraces at Dabat Research Station, North Gondar. Cogent Food \& Agric 6(1):1778604.

16. Amin MF, Hassan M, Barma NCD, Rehman M \& Hasan M (2015). Variability and heritability analysis in spring wheat (Triticum aestivum L.) genotypes. Bangladesh J Agric Res 40(3): 435-450.

17. Ullah H, Khan WU, Alam M, Khalil IH, Adhikari KN, Shahwar D, Jamal Y, Jan I, $\&$ Adnan M (2016). Assessment of $\mathrm{G} \times \mathrm{E}$ interaction and heritability for simplification of selection in spring wheat genotypes. Can. J. Plant Sci 96: 1021-1024.

18. Ullah I, Khalil IH, Rehman H, Mohammad F, Ullah H \& Khalil SK
(2011). Magnitude of heritability and selection response for yield traits in wheat under two different environments. Pak J Bot 43(5): 2359-2363.

19. Abid S, Masood MA, Anwar MZ, Zahid S \& Raza I (2018). Trends and variability of wheat crop in Pakistan. Asian J. of Agric and Rural Development 8(2): 153159.

20. Regmi S, Poudel B, Ojha BR, Kharel R, Joshi P, Khanal S \& Kandel BP (2021). Estimation of genetic parameters of different wheat genotype traits in Chitwan, Nepal. Int J Agron 1-10.

21. Khan AS, Salim I \& Ali Z (2003). Heritability of various morphological traits in wheat. Int J Agric Biol. 5(2):138140.

22. Afridi N \& Khalil IH (2007). Genetic improvement in yield related traits of wheat under irrigated and rainfed environments. Sarhad J. Agric 23(4): 965-972.

23. Nass HG \& Reiser B (1975). Grain filling period and grain yield relationships in spring wheat. Can. J. Plant Sci 55: 673678.

24. Moustafa ESA, Ali MMA, Kamara MM, Awad MF, Hassanin AA \& Mansour E (2021). Field screening of wheat advanced lines for salinity tolerance. Agronomy 11(281): 1-14.

25. Lozada DN, Ward BP, Carter AH (2020). Gains through selection for grain yield in a winter wheat breeding program. PLoS One 15(4): 1-18.

26. Rehman AU, Khalil IH, \& Ali I (2020). Genetic diversity and traits association in tetraploid and hexaploid wheat genotypes in Khyber Pakhtunkhwa Province of Pakistan. Sarhad J of Agric 36(4): 11121119. 